Article

\title{
Farmer Perceptions and Climate Change Adaptation in the West Africa Sudan Savannah: Reality Check in Dassari, Benin, and Dano, Burkina Faso
}

\author{
Daniel Callo-Concha
}

Department of Ecology and Natural Resources Management, Center for Development Research (ZEF), University of Bonn, Genscheralle 3, D-53113 Bonn, Germany; d.callo-concha@uni-bonn.de; Tel.: +49-228-731795

Received: 9 May 2018; Accepted: 19 May 2018; Published: 25 May 2018

\begin{abstract}
Climate change is a great threat to the already climate-unstable West Africa. Current and potential impacts are especially hard on farming in the Sudan savannah, thus adaptation is widely advised and encouraged, and already occurring. In the study sites Dassari, Benin, and Dano, Burkina Faso, farmers' climate change perceptions and practiced coping measures were qualitatively and quantitatively recorded. Analyses included statistical testing to detach anecdotal responses from factual decisions. Results reveal that responses regarding climate change perception and adaptation are frequently subjective, conjectural and inconsistent. Farmers' acknowledge that adaptations to climate change impacts are diverse, but site specific. Measures do not causally respond to the type of hazard, nor to its impacts, but instead tend to address wide-ranging demands, such as household food security, income generation and capitalization. Hence, causally linking hazards, impacts and responses can be misleading, and measures can thus be ineffective. After our findings, key qualities of effective coping measures are short-term economic returns, compatibility with local ecological, social and institutional settings and agreeing with the customary farming traditions. With respect to operability, the national agricultural extension services are still the most relevant instances. Considering these aspects can support local farming adaptation and also increase the general resilience of the households.
\end{abstract}

Keywords: West Africa; Sudan savannah; farming coping measures; subjective valuation; climate variability

\section{Introduction}

\subsection{Climate Change and Farmers' Perceptions}

The fifth assessment report (AR5) by the Intergovernmental Panel on Climate Change (IPCC) ratifies the increase in atmospheric $\mathrm{CO}_{2}$ concentrations and a consequent rise in global temperatures, which negatively impact the whole planet, but are especially hard on vulnerable regions such as the African continent [1]. The climate forecast for West Africa predicts increasing temperatures and decreasing and irregular rainfall. Time series analyses show that since 1970, temperatures have increased by between 0.5 and $0.8{ }^{\circ} \mathrm{C}$ [2], and since 1950, precipitation has decreased and is projected to drop by $10 \%$ over the 21 st Century $[3,4]$. This situation is exacerbated by inherent stressors such as poor soil fertility, scarcity of water and limited or inexistent infrastructural and institutional support, which also hamper the promotion of adaptation and the enforcement of mitigation actions due to technical, managerial or financial limitations [5-10].

Farmers' interest in climate mainly regards the need to forecast weather to adjust their cropping decisions [11]. This information has often been disregarded by scientists as a source of reliable 
knowledge [12]. Recent studies tend to reconsider this, since it is believed that local and traditional knowledge can provide useful insights about local climatic systems and on peoples' vulnerability, resilience and adaptability [13]. However, the integration of local and scientific knowledge is still limited by the incomplete understanding of local knowledge systems and the lack of approaches and tools to integrate both [13-15].

The latest research has hypothesized the existence of links between farmers' and other stakeholders' climate change perceptions and valuation, as well as their responses with climate records [16-18]. In the case of West Africa, although there is a general coincidence between scientific and farmer observations that indicates 'less and increasingly irregular rainfall periods and longer and drier spells' [9,19], it is known that farmers' perceptions may differ for several reasons, e.g., degree of involvement with the market, gender and ethnicity, general political, economic and geographic settings and supernatural and fatalistic beliefs [20-22].

\subsection{Implementation of Adaptation Measures}

Technically, farming adaptation refers to minimizing the carbon and nitrogen concentrations in the air, vegetation and soils and promoting the efficient use of macro- and micro-nutrients in physiological processes [23]. For West Africa, the scientific literature suggests measures to increase soil fertility, such as the use of improved technologies, e.g., minimum tillage, compost, mulching, rotations with legumes, and the encouragement of retention and storage of carbon and nitrogen [24-27]. To cope with water scarcity, the use of supplemental irrigation, improvement of storage capacities, utilization of surface and shallow groundwater and strengthening of community-based management are recommended [28-30].

However, despite being based on sound science, the implementation of these measures does not always increase farmers' adaptive capacities [31]. Other factors may hinder farmers' adaptation to climate change, such as the lack of sound weather forecasts, poor access to financial means, depleted natural stocks, farmland scarcity and insecure land tenure and limited access to inputs [20,32-35]. In general, these factors are related to poverty [36] and rarely to knowledge [32], which supports the assumption that the economic, political and social conditions are at least as important as the reactive measures [37].

Hence, it is clear that in order to succeed, adaptation measures have to suit the local biophysical conditions [38-40], provide complementary goods, benefits and services to householders [41], enlarge the scope to broader scales, mainly in terms of policy and trade [42], and finally, due to the high unpredictability of climate change and variability, embrace resilience as a key feature [42,43]. In order to be feasible, multilateral settings and enhanced partnerships between governments, non-governmental and even private organizations are necessary $[44,45]$. In this regard, a number of local studies have corroborated the success of specific measures in specific settings [20,22,34,35,46,47]. However, these studies refer mainly to farmers' perceptions, in general based on estimated and secondary data. This simplifies the complexity of the adaptation phenomenon by focusing on specific insights and practices disconnected from their context and other interacting factors.

In the above-depicted context, this study investigated the perceptions and adaptive behavior of West African farmers regarding climate change and variability. First, the farmer perceptions concerning the causes, impacts and local alternatives for dealing with changes in their situation were investigated (Section 3.1); second, the type, extent and relative importance of their coping measures were identified and assessed (Section 3.2) and framed within institutional contexts (Section 3.3). The results were cross and statistically analyzed revealing their shortcomings and inconsistencies. Based on this, dominant positions and reports regarding farmers' climate change perceptions and adaptations can be observed and lessons extracted for a more effective policy design and implementation. 


\section{Materials and Methods}

\subsection{Research Sites}

The West African Sudan savannah is very climate sensitive [48]. Major drivers are the InterTropical Convergence Zone (ITCZ) that determines the 'harmattan', i.e., wind fluctuations from the Gulf of Guinea and the Sahara desert, and the constant solar radiation, which together lead to short unimodal rainy seasons, a hot and dry climate and daily and seasonal variations in temperature and relative humidity $[29,49]$. The landscape is mainly shaped by human activities. Agricultural fields and grasslands with trees (parklands) dominate over scattered forest patches; streams are drained and ephemeral; and natural fauna is depleted and restricted to conservation zones [50].

Farming systems are extensive, subsistent, low-input-based and rainfall dependent. Land-use intensity diminishes with increasing distance from the homestead. Fallowing is still the main way to restore soil fertility. Cropping systems are dominated by drought-tolerant cereal species such as sorghum (Sorghum sp.), maize (Zea mays) and millet (Pennisetum sp.), legumes, e.g., groundnut (Arachis hypogea) and cowpea (Vigna unguiculata), as well as crops with a high market value, such as cotton (Gossypium hirsutum). Livestock is ubiquitous and multipurpose and often interacts with cropping systems, but is of low technical standard [8,51-53].

In these settings, two catchment sites were studied, i.e., Dano in Burkina Faso and Dassari in Benin. These sites were ex-ante selected as part of the West African Science Service Center on Climate Change and Adapted Land Use (WASCAL; http:/ / www.wascal.org/, which is a regional organization with the mandate to enhance the understanding, data availability and local capabilities to increase farming systems' abilities to cope with climate change). In this common sampling frame, several experiments and systematic data collection took place successively. Both catchments are located along the same latitude $\left(11^{\circ} \mathrm{N}\right)$ and therefore may share biophysical and ecological conditions, but it is assumed that they differ in their socioeconomic characteristics (Figure 1). This was of fundamental importance, as we did not intend to compare performance, but to detect differences useful for operationalizing technical and policy-related suggestions.

Dassari arrondissement belongs to the municipality of Materi, Atacora department, located in north-west Benin, $30 \mathrm{~km}$ from the border with Burkina Faso and Togo and $75 \mathrm{~km}$ from Natitingou, the department capital city. The arrondissement comprises 17 scattered villages developed near small dwelling agglomerations, markets and roads; in 2006, the population was 23,000 [54]. Annual rainfall exceeds $1000 \mathrm{~mm}$, distributed in a bimodal pattern, while the annual average temperature is $28.7^{\circ} \mathrm{C}$ with maximum peaks over $40{ }^{\circ} \mathrm{C}[55,56]$ (Figure 1 ). The natural vegetation varies seasonally depending on water availability, although the area is mostly deforested and consists of grazing and farm lands. The main crops are sorghum, beans, maize and cotton [55,57]. According to the FAO classification, soils are Ferric Lixisols characterized by poor macronutrient and organic matter content and of limited depth due to their lateritic origin, often suffering from crusting and compaction [19]. Water bodies are scarce and often affected by sand sedimentation [57].

Dano is a department and in the Ioba province located in south-western Burkina Faso about $250 \mathrm{~km}$ from the country's capital Ouagadougou. The department covers $669 \mathrm{~km}^{2}$ and counts 22 rural villages and one urban center. The population is estimated at 44,000, and the area has the highest population density in Burkina Faso [58,59]. Annual rainfall is about $1000 \mathrm{~mm}$ in a bimodal regime, and temperatures range from a minimum of $20.1{ }^{\circ} \mathrm{C}$ to a maximum of $38.4{ }^{\circ} \mathrm{C}[56,60]$ (Figure 1). The original dominant vegetation consisted of scattered trees and perennial grasses, but it is now replaced by annual crops such as millet, sorghum or maize cultivated in monoculture or associations. Dominant soil types are Lixisols with poor nutrient content, low water-holding capacity and high erodibility, as well as Cambisols (silty clayey) and Leptosols (clay, loamy and very shallow) [59,60]. 

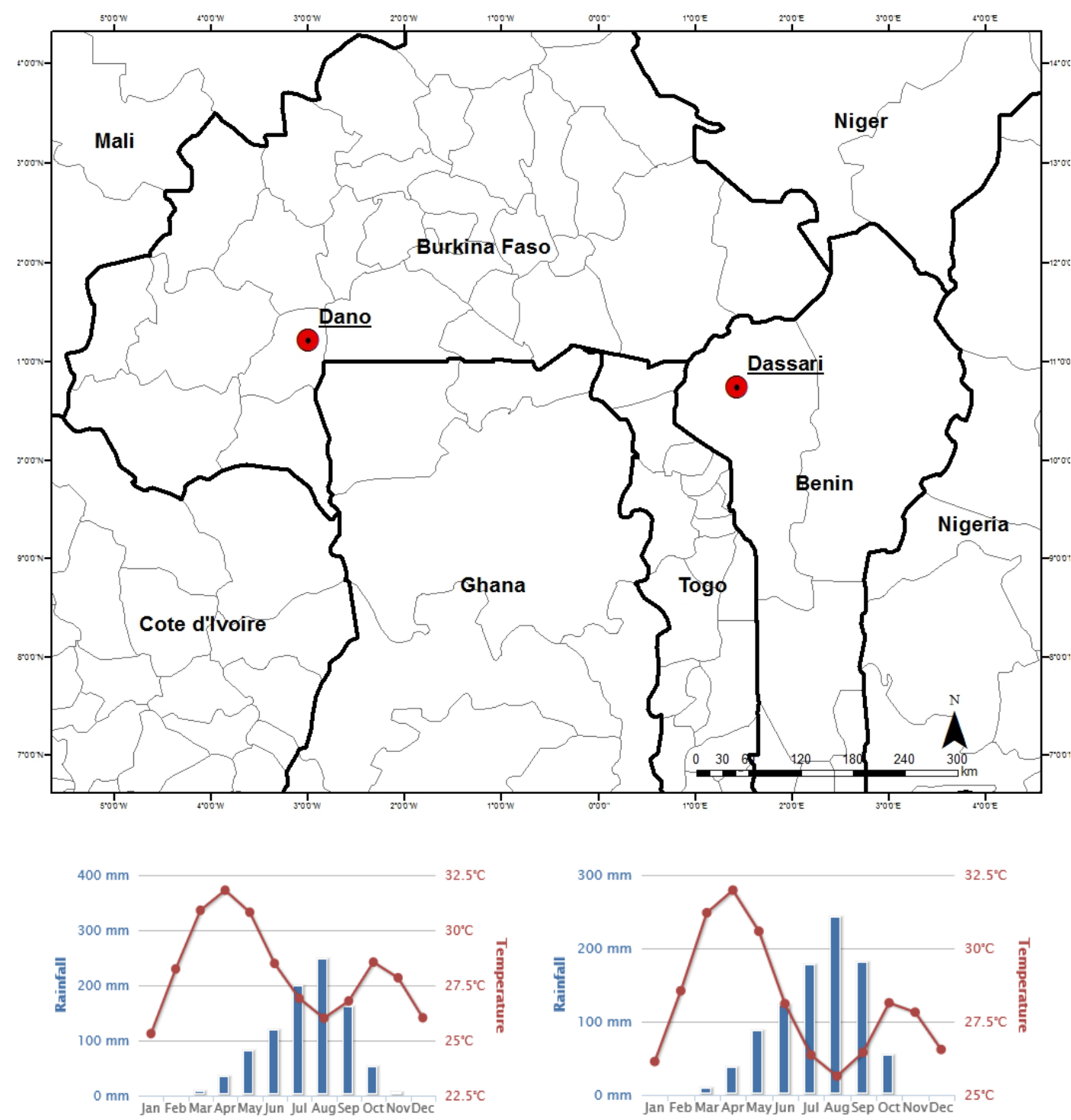

Figure 1. Location of study sites in West Africa. Average monthly temperatures and rainfall for Dano (left) and Dassari (right) adapted from [56,61].

\subsection{Methodology}

In this study, multiple and interdisciplinary techniques for data collection and analyses were applied. They combined group and targeted interviews, extensive quantitative household surveys and statistical testing. Results were cross analyzed to identify consistency to extract valid outcomes.

Prior to data collection, explorative group interviews were carried out in each catchment. Applying free listing and image elicitation methods, farmers were asked about their views on major climate change-related hazards and the effects on their livelihoods. Based on their responses, a survey and guidelines for semi-structured interviews were designed.

Considering farmers' climate change perceptions and ongoing coping measures as crosscutting themes, semi-structured interviews were carried out with two categories of stakeholders to obtain traditional and institutional perspectives: (1) elderly members of the community (Benin $n=5$ and Burkina Faso $n=6$; sampling stopped after reaching theoretical saturation) who were on average about 65 years old, male, retired farmers and now housekeepers and/or caretakers of children. They were asked about their opinions on the causes, who they thought was responsible and adequate responses 
to climate change. (2) Local leaders of agricultural government agencies (Benin $n=3$ and Burkina Faso $n=3$ ), i.e., Ministry of Agriculture, Water Resources and Fisheries of Burkina Faso (Ministère de 1'Agriculture, des Ressources Hydrauliques; MARH) and Ministry of Agriculture, Livestock and Fisheries of Benin (Ministère de 1'Agriculture de l'Elevage et de la Pêche; MAEP), multilateral institutions with climate change-related mandates such as the program of Agricultural Development of Burkina Faso (Programme Développement de l'Agriculture; PDA), and in Benin, the Centre of Regional Action for Rural Development (Centre d'Action Régional pour le Développement Rural; CARDER) and also representatives of a private foundation and non-governmental organizations (NGOs).

Finally, a survey was applied to a representative number of randomly sampled households ( $n=140$ in Dassari and $n=122$ in Dano). In all cases, the head of the household was the main source of information. The survey covered four domains, i.e., description of the household, characterization of the farming system, the farmer's perception of climate change and variability and the main coping measures. The survey was designed in French, but implemented by local enumerators in the local languages (Dagara in Dano, and Biali in Dassari). Households and coping measures were characterized and geo-localized.

Farmers' responses were analyzed using discourse and statistical analyses, including measures of central tendency and dispersion, and sampling distribution (Chi-squared test). Quantitative responses on the occurrence of extreme events were overlaid with climatic records and their accuracy evaluated. Finally, concordance and symmetry analyses (Kappa and McNemar tests) assessed the consistency of crop selection in successive seasons and farming plots. The software used was SPSS and STATA. Data collection and analyses complied with ethical standards that secured a respectful and safe treatment of the information and identity of participants.

\section{Results and Discussion}

\subsection{Farmer Perceptions}

Farmers' perceptions were assessed in three successive phases, i.e., explorative group interviews (later used to design the survey), interviews with elderly farmers and an extensive household survey. The results of the survey were assessed quantitatively and statistically.

\subsubsection{Group Interviews}

The results of the explorative group interviews show that farmers mentioned variability in rainfall, wind and heat as the main climate-related causes of distress. They also argued that the main effects on farming were lack, scarcity and variability of water, increased number of pest attacks, soil loss and lack of feed for cattle. The opinion was widespread that human health was affected by changes in the climate.

Asked about their responses to these difficulties, the farmers mentioned infrastructural measures, such as the construction of dams, ponds and wells for water storage. Agricultural techniques like soil fertilization, manuring and soil conservation through stone bunds and general activities such as planting trees for multiple benefits and temporary out-migration as the last option were also mentioned.

\subsubsection{Interviews with Elderly Farmers}

In the interviews with the elderly farmers, climate change was broadly acknowledged. All interviewees stated that these changes affected the climate seasonality and highlighted impacts on yields. Their statements, however, often referred to factors beyond the climate realm:

"Everything has changed. The heat. There is a lot of heat. Before there was not much heat [... ], the wind, the wind is too much, too fast [ . . ] brings the illnesses, diseases. The rain also. Everything has changed!" "Nature had a calendar that was respected, now there is no longer such a calendar. It used to indicate when to start [agricultural activities], now it just happens like that... " (Mr. D. K., Dassari, 20 April 2013) 
"Before, with my dad, a small portion [of land] used to gain a lot, now with a large portion one does not gain a lot. There is no fertility anymore, the rain, it is not as before, there is a change." (Mr. P. D., Dano, 26 April 2013)

In contrast, the causes of the changes appeared blurred to the farmers. The answers tended to diverge, stating fatalistic and supernatural forces, as well as human activities as a major cause, which they had probably heard from extension and NGO agents.

"It can be called: 'la vie d'aujourd'hui' (the life of today). This is the expression! The change we can see. [ ... ] Nowadays there are no trees. The rain is rare. Cannot say why it is like this nowadays. I do not know why. I have seen the changes but I do not know who is responsible" (Mr. D. K., Dassari, 20 April 2013)

"It is only God who knows who is responsible" (Mr. S. Y., Dano, 27 April 2013)

"Before, there were the totems which forbade us to do certain things. But meanwhile the [fellow] Africans have started to do what is forbidden [ .. . ] and the change was sent. Voila!" (Mr. S. O., Dano, 25 April 2013)

"There is no responsibility, neither by the government nor by anybody else. It simply does not rain and the soils are poor" (Mr. J. L. D., Dano, 24 April 2013)

"The first issue is the man. That is it. When my grandpa was here there were lots of trees, big trees. He did not chop [cut] them. Now we have chopped all of them! It is the man! [Q: Maybe there are other causes?] No, no! It is the man. Is the man, the one that does it. It happened, in the time of my mom [ ... ] she watched the foreigners who came, who confirmed that the man was the problem, and now we gradually understand, and therefore have to change [ ... ]" (Mr. A. Q., Dano, 20 April 2013)

When asked about alternatives to cope with climatic impacts, elderly farmers tended to combat the hazards by focusing on resources management, but they also referred to organizational and institutional aspects. However, mystical and supernatural arguments complemented the picture.

"In the past you could work the field [because the soil was fertile], now you are obliged to utilize chemicals! To use organic manure and ask for fertilizer from the government. So we use both! [ ... ] If we were not be able to use the fertilizer for farming we would have to leave to look for new lands. So the organic manure and the fertilizers from the government!" (Mr. D. K., Dano, 20 April 2013)

"A way to address the change is: In the past there were reunions and now one calls the people to come but they do not come. Then the solution is to attend the meeting and find the solution. So there is [will not be] no problem" (Mr. S. O., village chef, Dano, 25 April 2013)

"We have to ask for an excuse. We have to ask for pardon. To him who knows [the 'Sage': local wise man], who knows what comes, who knows what is the truth. He is who knows and watches the fetish to ask him to pray to bring the weather back from before" (Mr. D. K., Dassari, 20 April 2013)

\subsubsection{Household Survey}

Regarding having heard of climate change, neither positive, nor negative farmer responses showed significant differences $(p<0.05)$. Information from the media is limited, and so is institutional outreaching, as also observed by Eguavoen and Wahren [62]. Thus, the awareness of climate change seems limited. Hence, farmers' climate change knowledge is mainly based on their "own" experience and interpretation and therefore not aligned with mainstream discourses. 
In all subsequent questions on climate, the retrospective time frame was 10 years, except for farming activities, e.g., crop selection, where it was five years. Questioned about changes in climatic elements during the past 10 years, about $60 \%$ of the farmers in Dassari and $80 \%$ in Dano believed that rainfall had decreased and that temperatures and wind had increased. Variability of rainfall, temperature and wind was perceived to be considerably higher in Dano with 35.5\%, 19.8\% and 10.7\%, respectively, compared to Dassari with $13.9 \%, 2.2 \%$ and $4.4 \%(p<0.01)$. Concerning the importance of the ensuing hazards, droughts were mentioned by more than $80 \%$ of the farmers in Dassari and droughts and floods in Dano by $30 \%$ and 35\%, respectively. However, $10 \%$ of the farmers in Dassari and more than $40 \%$ of the farmers in Dano $(p<0.01)$ denied having experienced climate-related hazards. Nevertheless, $91.4 \%$ of the farmers in Dassari reported being hit by droughts and $62.5 \%$ by wind; in Dano, the values were $71.9 \%$ and $35.5 \%$. Floods ranked low in Dassari and were not significant for Dano $(p<0.05)$.

The perception of hazards may relate to the local biophysical settings, e.g., hilly landscape and profuse lateritic soils in Dano, which increase the vulnerability to floods there. Similarly, the flat terrain and absence of streams increase the proneness of Dassari to droughts. In contrast to the few mentions in literature, e.g., [63], farmers in both catchments stated almost unanimously that wind/storms were a major climate change-related hazard.

With respect to the impacts on farming, the survey showed a consensus about the increase in pests and diseases in crops and livestock, as well as in soil loss. This also applied to the decrease in crop yields, livestock population and water availability, as well as to fluctuating water availability $(p<0.01)$ (Figure 2). These findings are in line with previous reports $[5,6,64,65]$ with the exception of livestock diseases, which were perceived as particularly acute in the study region and are comparatively underrepresented in the literature.

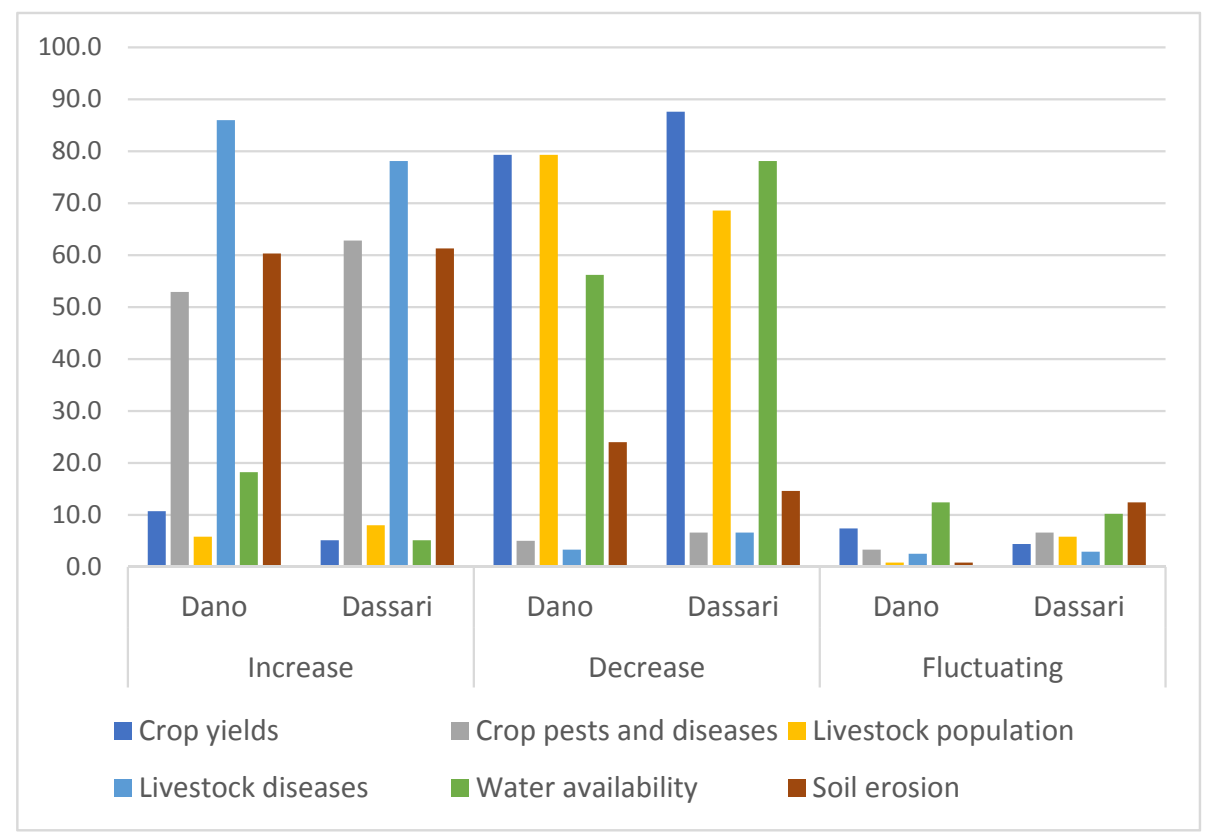

Figure 2. Farmers' perception of the increase, decrease and fluctuation in farming variables due to climate change in Dassari and Dano in percentage (valid responses $\chi=90.4 \%$ ).

The contribution of farming activities to climate change was seen as being of great or very great importance: burning of the vegetation (86.8\% for Dassari and $75.2 \%$ for Dano), cutting of trees $(88.3 \%$ and $92.6 \%)$ and the increase in agricultural land $(64.3 \%$ and $43.0 \%)$. The use of fossil fuels and the increase in population were non-significant $(p<0.01)$. Again, the results are consistent with previous studies, where land use conversion is mainly associated with slash-and-burn and forest logging $[66,67]$. 
Overlapping results on farmers' perception of climate change and reports of harm to their own livelihoods show that various issues were not sufficiently considered. For instance, the proportion of farmers that stated 'not having heard of climate change' is $40 \%$ lower than 'having experienced impacts of climate change'. This indicates an apparently lacking relationship between these two issues from the viewpoint of the farmers. Furthermore, droughts in Dassari, and less importantly floods and droughts in Dano, are highlighted as major climate hazards; these are also noted in national reports [68]. However, when referring to hazards, floods and wind/storms seem more relevant. This questions the role of floods, often prominent in reports, and reveals the role of wind/storms, often unaccounted for or neglected due to their association with the harmattan (Figure 3).

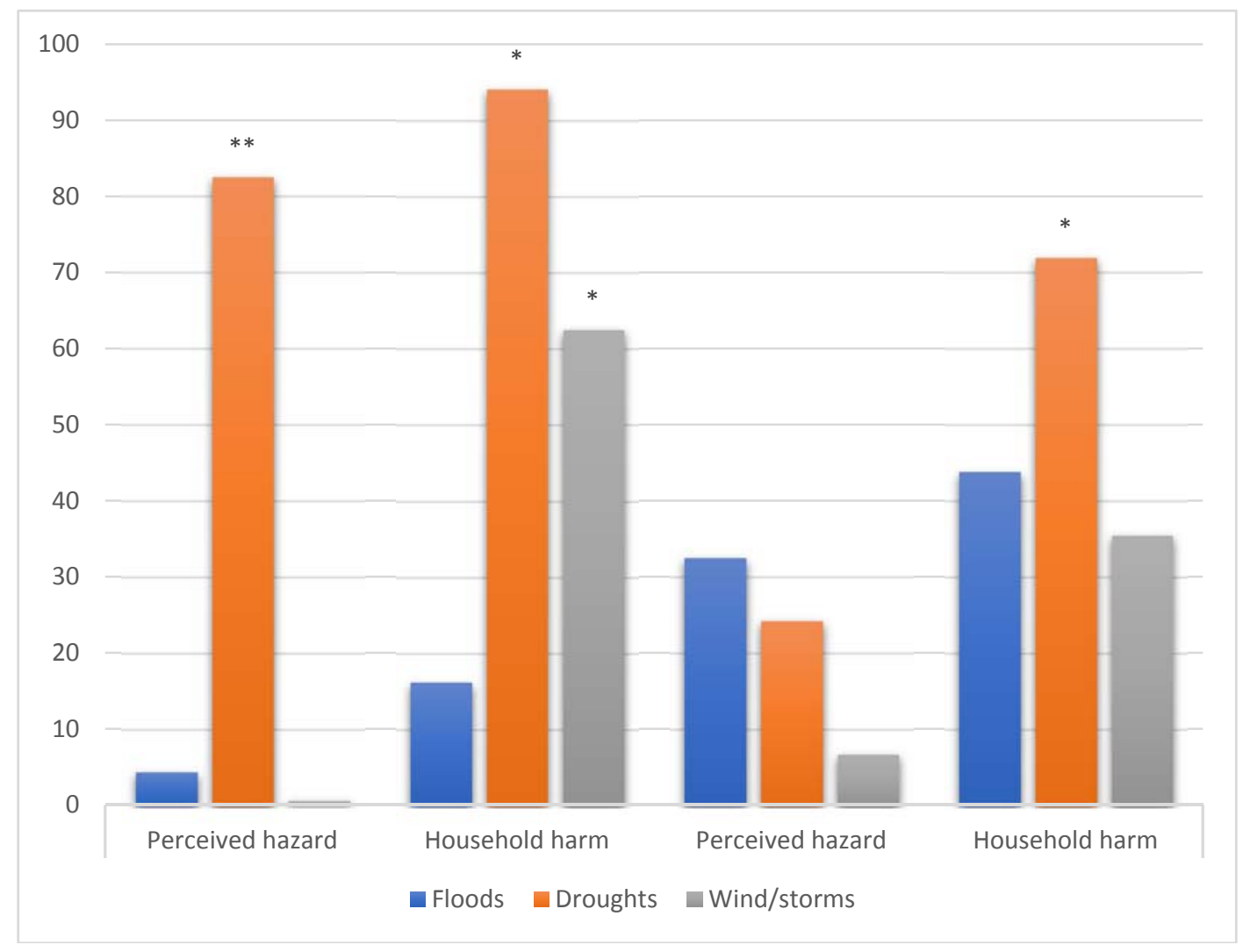

Figure 3. Farmers' perception of climate change-related hazards and the direct harm to their livelihoods in Dassari and Dano in percentage $\left.{ }^{*} p<0.05,{ }^{* *} p<0.01\right)$.

Regarding the occurrence of extreme events (shocks) within the past 10 years independent of damage to livelihoods, the responses at both sites were emphatic: $94.2 \%$ in Dassari and $75.2 \%$ in Dano $(p<0.01)$. However, when the farmers were asked about the details of these extreme events (type of shock, period of occurrence, number of occurrences), responses were less categorical. The average number of occurrences was low, and median values did not exceed two (out of 10 years). Furthermore, the dispersion is high and the lower quartiles predominate, whilst outliers tend to overestimate the shock occurrences (Figure 4). 


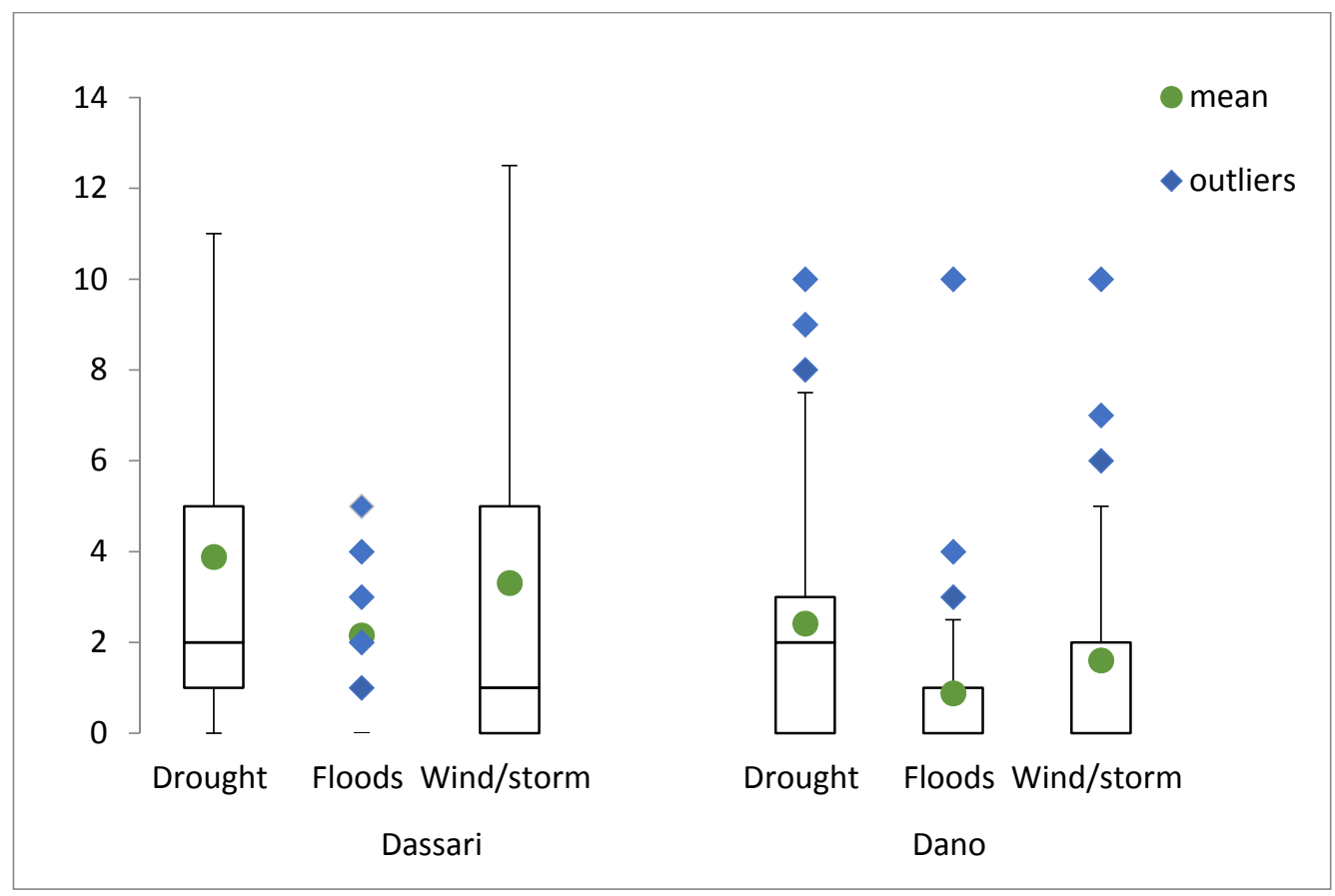

Figure 4. Distribution of farmers' perceived occurrences of extreme events in Dassari and Dano 2002-2012.

Moreover, assigning responses regarding extreme events to specific years and overlapping these with records of cumulated rainfall during the rainy season (June-September) and average temperature in the dry season (February-May) reveals poor or no fit (Figure $5 a, b)$. This is confirmed by estimating the correlation coefficients and crosschecking the reported peaks, e.g., 2006 and 2008, with documented drought occurrences [69]. All in all, this indicates a subjective (often exaggerated) evaluation of extreme events.

\section{Dassari $(n=136)$}

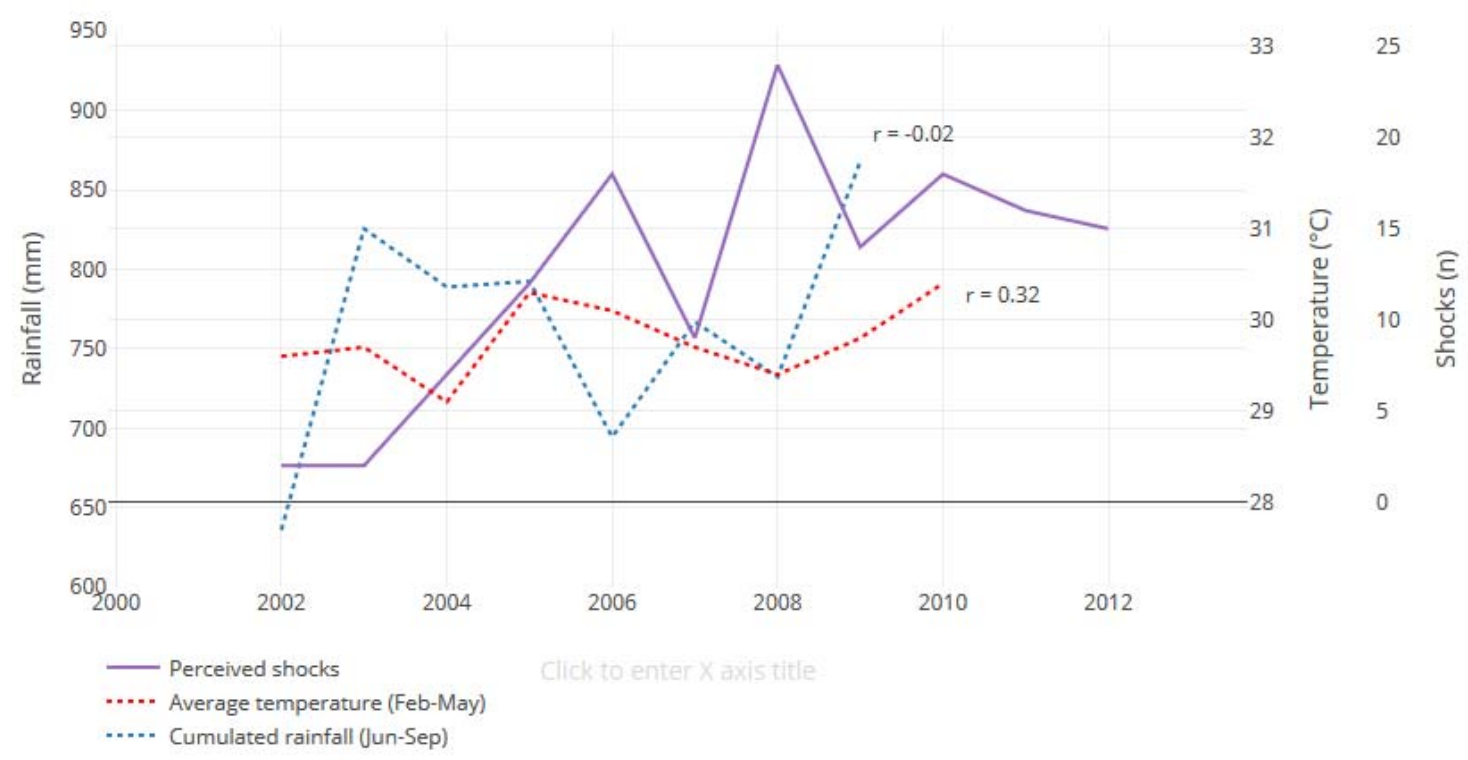

Figure 5. Cont. 


\section{Dano $(n=121)$}

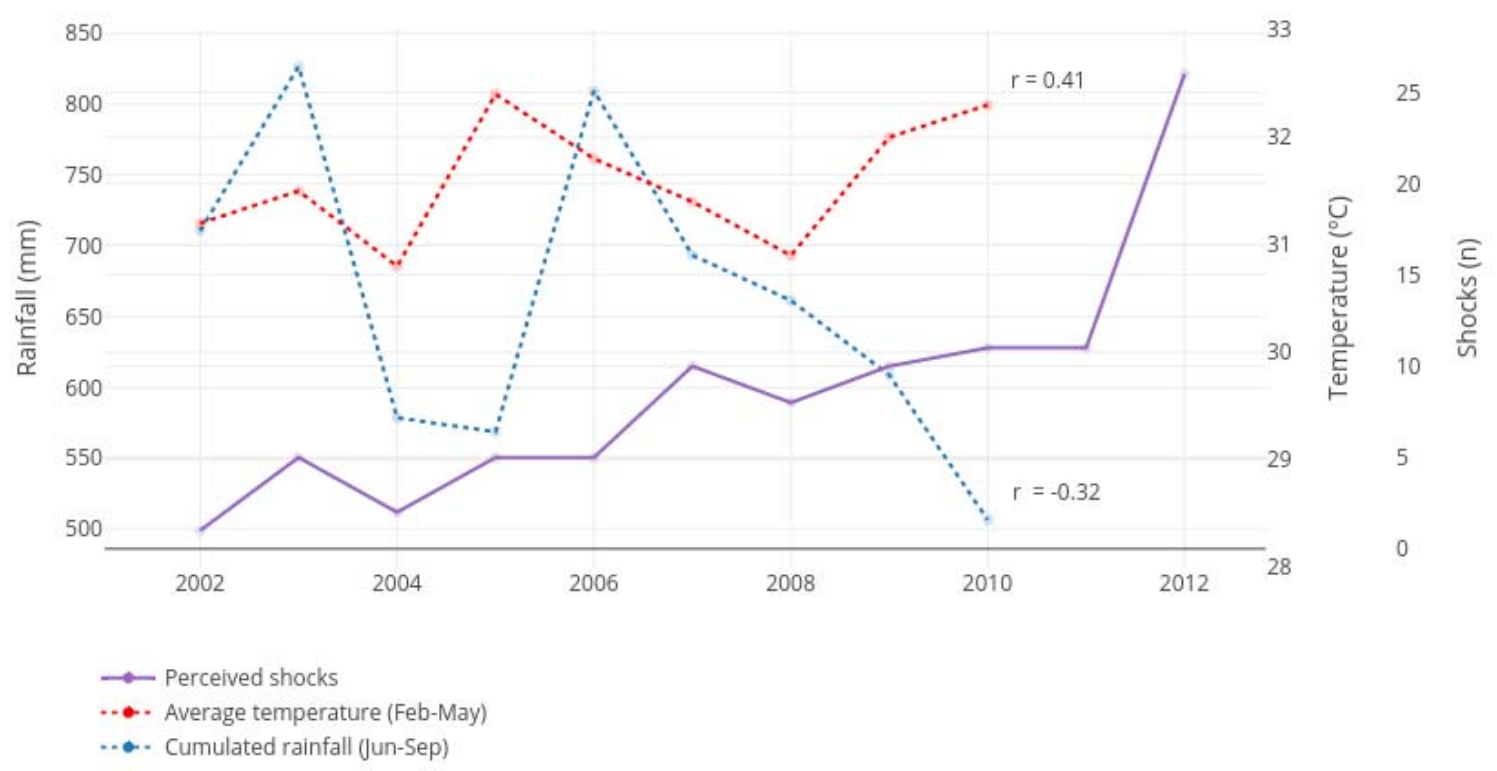

Figure 5. Farmers' perceived number of extreme events versus rainfall and temperature records (2002-2012), in Dassari and Dano [70-72].

\subsection{Coping Measures and Adaptation Strategies}

Farmers' coping measures were quantified via an extensive survey and statistically analyzed for representativeness and consistency.

Asked about specific measures on their own farms, $94.2 \%$ of the farmers in Dassari and $97.5 \%$ in Dano confirmed having implemented at least one coping measure $(p<0.01)$. Responses were categorized by type, i.e., land/soil, cropping, livestock, modern technologies and market related. On average, each farmer carried out three soil-related practices, but only one crop- or technologyrelated practice. With regard to livestock, almost every farmer did something about this in Dano, but in Dassari, only three out of ten did so. Market-related measures were practiced by ca. $10 \%$ of the Dano farmers, but by about 33\% in Dassari.

Soil fertilization was the most widespread coping measure. Roughly $50 \%$ of the farmers applied synthetic fertilizers and organic amendments (mainly manure). Physical conservation practices, such as stone bunds or ridges, were predominant in Dano (83.4\%), and in Dassari, spatial measures, such as fallows, enclosures and expansion or reduction of plots were predominant (83.9\%) (Figure 6a). The use of improved, adapted and resistant varieties was equally widespread, with $42.4 \%$ of households in Dassari and 57\% in Dano cropping such varieties. The introduction of prospective new species reached $22.3 \%$ in the farm households in Dassari and 38\% in Dano. Off-season farming was observed in about $12 \%$ of the households in both catchments. Tree- or forest-related practices were restricted to Dassari with only 13.1\% (Figure 6b). In relation to livestock, in Dano, the number and diversity of implemented measures greatly exceeded those in Dassari (Figure 6c). Regarding modern technologies, agrochemicals were used by $32.1 \%$ of the farmers in Dassari and by $47.1 \%$ in Dano. Mechanization and post harvesting varied from $13.2 \%$ in Dassari to 33.9\% in Dano, while irrigation was virtually inexistent among the sampled households (Figure 6d). Finally, the organization and marketing of agricultural products was limited to $20.4 \%$ of the households in Dassari and $10.9 \%$ in Dano. 


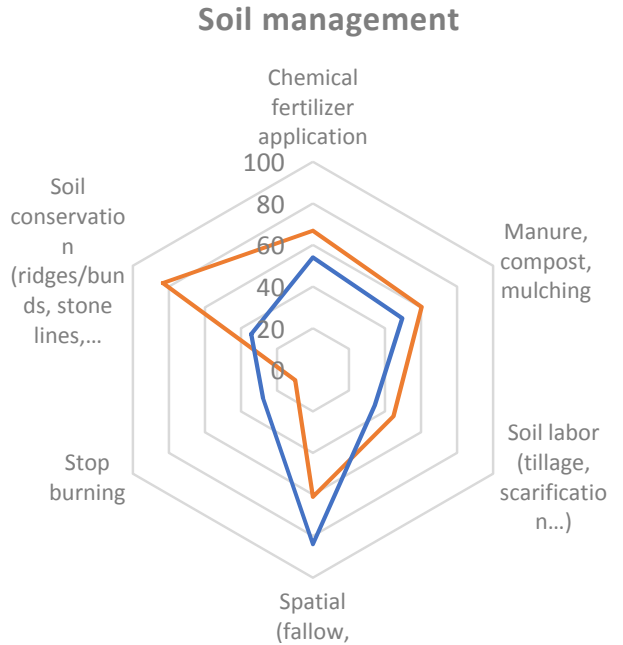

Livestock management

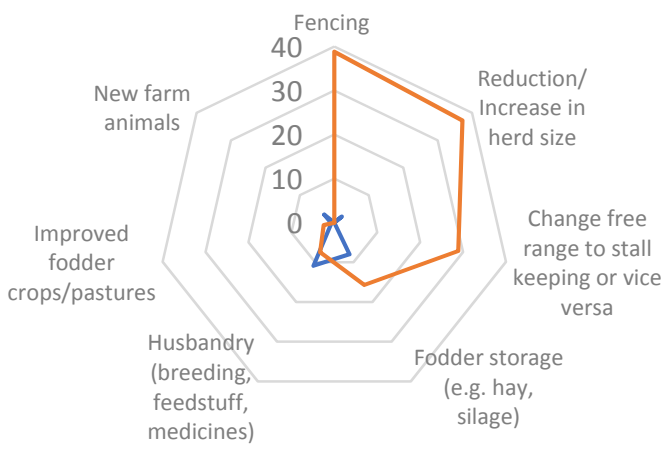

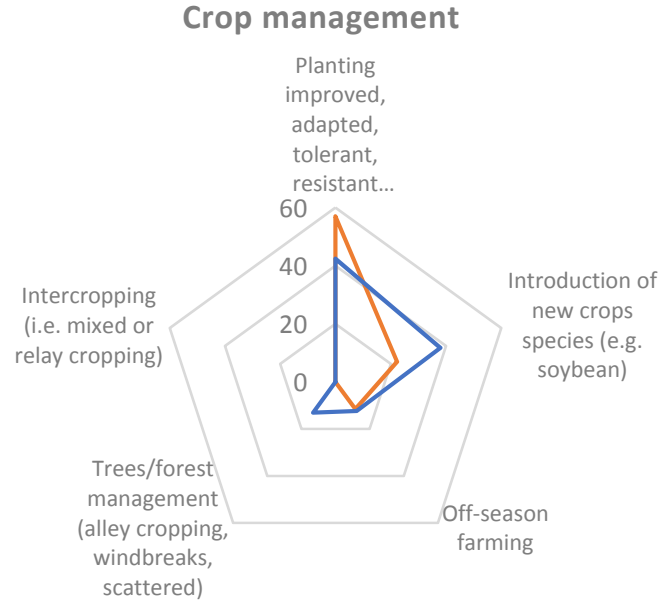

Improved technologies

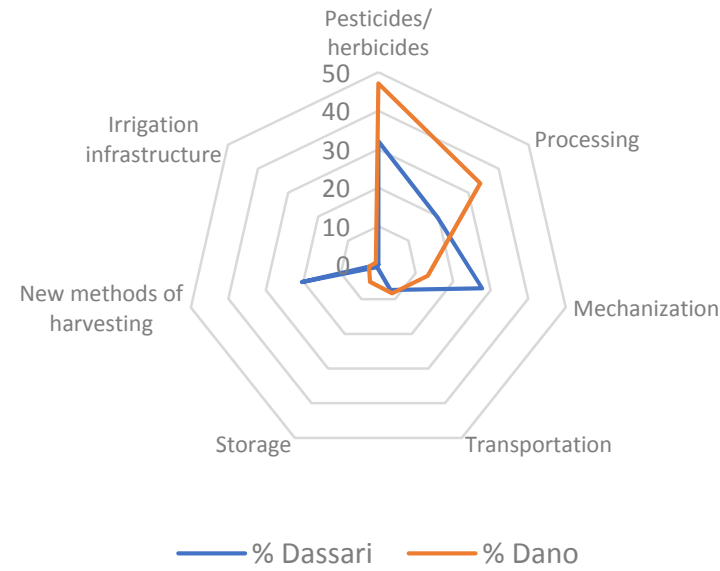

Figure 6. Percentage of coping measures implemented by farmers per category in Dassari $(n=136)$, and Dano $(n=121)$.

The motivation behind the adoption of a specific set of agricultural practices was diverse. In the case of soil-related practices, it was mainly the amelioration and recovery of soil fertility and the prevention of soil loss, especially against hydraulic erosion. Crop-related practices in Dassari were control of pests, increase in production, prevention of famines, etc., while in Dano, production diversification and market opportunities were more important. The main reasons for livestock-related practices were protection of herds, animal health and the side accumulation of manure. Technology-related practices, such as pest control and mechanization, were justified by the strong relation with cash-crop cultivation; this also applied to marketing and organizational practices.

Three underlying reasons for the activities can be assumed. First, the climatic homogeneity of both study sites is partially overpowered by their ecological and socioeconomic differences, e.g., soil physical conservation practices dominate in Dano due to the sloping landscape, whilst the spatial-related practices in Dassari are due to the predominantly flat landscape. Second, market and institutional forces greatly influence the selection and implementation of adaptation practices, e.g., the subsidy programs for export crops such as cotton, which encouraging the use of agrochemicals, mechanization and transport. Finally, there was a long history of extension activities of the government and NGOs, recognizable in the implemented field practices and justifications by the farmers.

Furthermore, the consistency of responses concerning crop selection was assessed. The hypothesis that crop/species selection is climate change dependent or is for other reasons was tested using 
concordance (Cohen's kappa) and homogeneity (McNemar) tests [73]. Farmers were asked about the crops they had cultivated in the past five years in their five main plots (Supplementary Material).

Results show a hierarchy in the allocation of specific crops to specific plots, most likely in relation to their market value and potential economic revenues. Hence, the more fertile plots were cultivated with cash crops (cotton and rice) and the other plots with food crops, which seems to follow a prioritization: staple crops, cereals, beans and vegetables, maybe based on the proportional provision of carbohydrates, protein and vitamins. This is shown by linking (dotted lines) the average percentage values of cotton, maize and beans (Figure $7 \mathrm{a}, \mathrm{b}$ ).

If, as hypothesized, farmers had changed their crop selection based on observations of climate and weather, we would see this in the findings of crop choices. However, this was not the case. On the contrary, results show that crop selection is more likely to be an ad hoc decision implemented in response to specific needs and framed into broader contexts, which include financial income, maintenance and increase in soil fertility, customary choices and food and nutrition security, which may refer to climate change, but not exclusively.

Dassari $(n=136)$

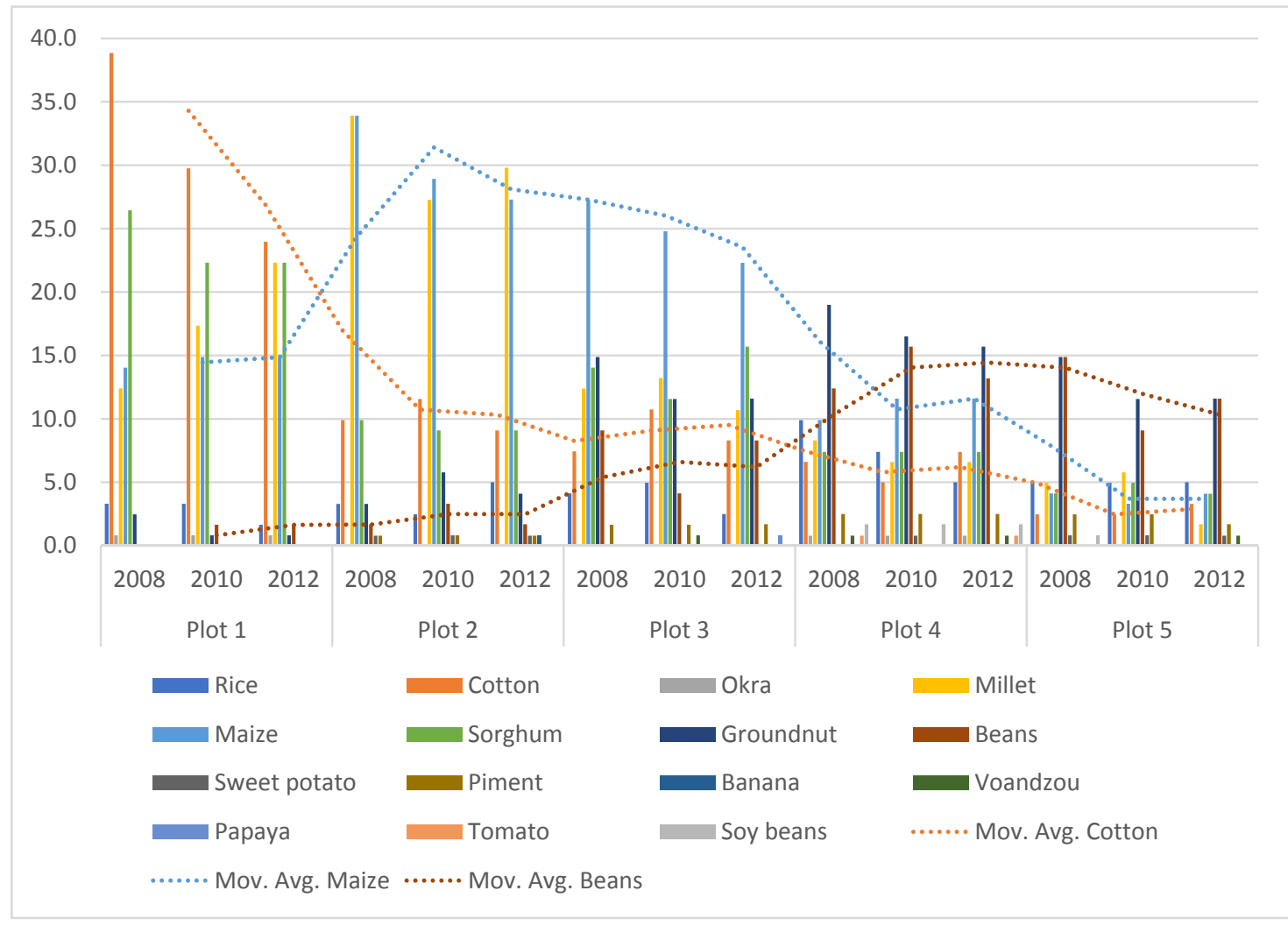

Figure 7. Cont. 


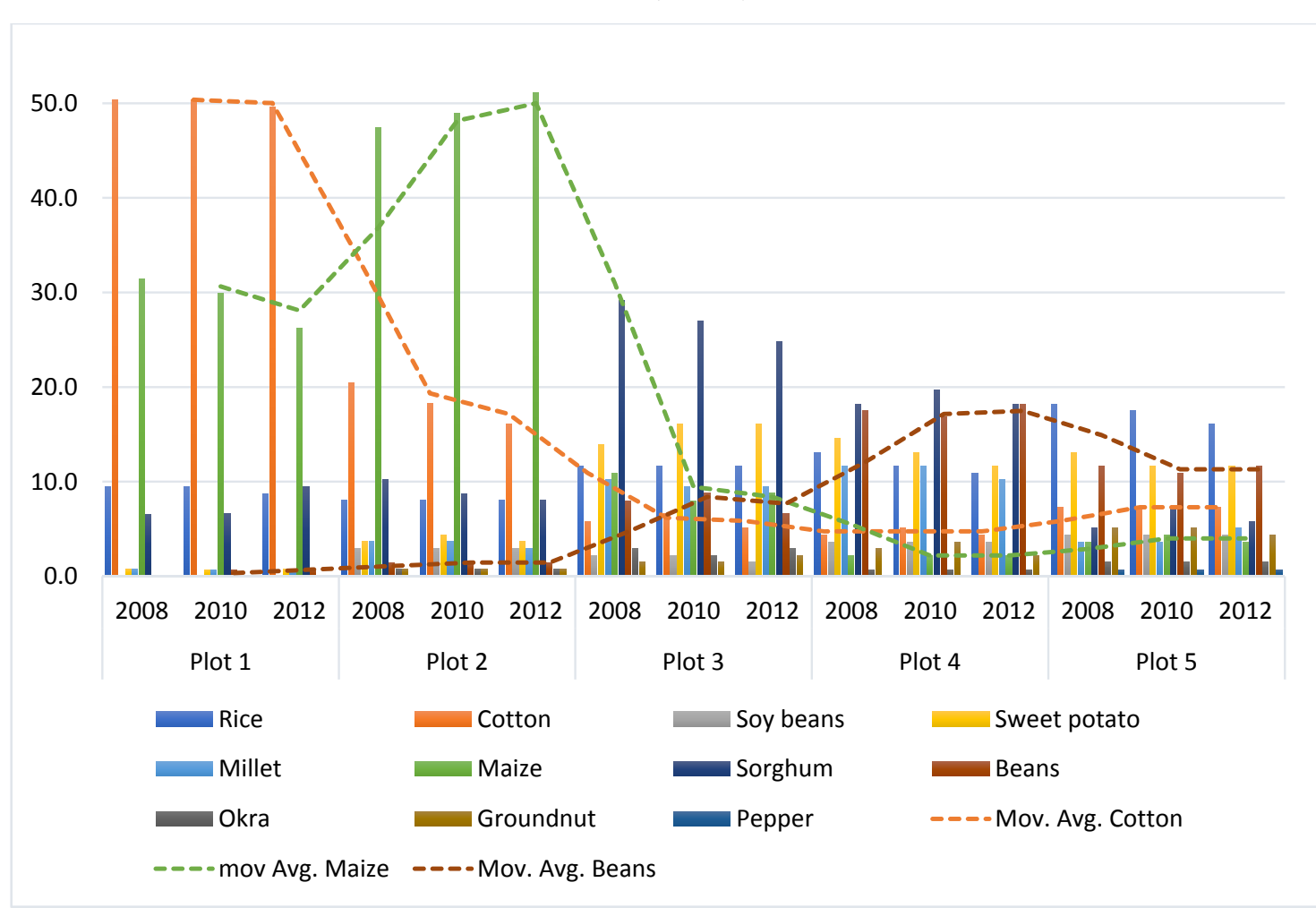

Figure 7. Percentage of farmers' crop choice in five main plots for 2008, 2010 and 2012 and trends (moving average) of selected crops in Dassari and Dano.

\subsection{Views of Government Agencies and NGOs}

A broad spectrum of governmental agencies and non-governmental organizations (NGOs) operate in both catchments. Interviewed representatives seemed to have embraced the mainstream discourse of climate change: 'Global warming effects are greatly hampering rural householders' well-being and there is a need to respond promptly'. The mentions of local impacts are based on customary observations and do not differ from those by farmers, e.g., irregular onset, duration and end of rainfall periods, etc.

Activities by the government agencies, however, were not based on rhetorical discussions on climate change, but rather on customary agendas that prioritized good agricultural practices, such as soil conservation, use of organic amendments, introduction of improved varieties, etc., generally in the form of traditional extension approaches such as demonstration parcels. Officers reported a chronic lack of financial and material means as the main reasons for the lack of activities (I. A., high-level officer, Ministry of Agriculture, Livestock and Fisheries of Benin (Ministère de l'Agriculture de l'Elevage et de la Pêche; MAEP) Tanguieta 15 April 2013, and S. M., high level officer of the Ministry of Agriculture, Water Resources and Fisheries of Burkina Faso (Ministère de l'Agriculture, des Ressources Hydrauliques; MARH), Dano 22 April 2015).

In the case of NGOs, agendas are similar, but also subject to changes determined by funders' priorities and the terms and time frame of funding. Whilst in the past, field activities focused on agricultural production, later, more emphasis was placed on credit provision and organization for commercialization, and more recently on emerging issues such as HIV prevention and public health, urban sanitation and safeguarding of wildlife (M. O., director local NGO, Dano, 24 April 2013).

Although government officers and representatives of NGOs acknowledge the existence of National Adaptation Programs of Action (NAPA), these have not yet developed comprehensive and countrywide action plans, as they still lack logistic and financial means. Former efforts were fragmentary and 
modular, focusing on small areas with identified vulnerabilities and testing of ad hoc adaptation practices. This strategy has recently been reinforced by the financial support of international donors and the operational assistance of international and national consultants. Existing institutions have enlarged and reframed their portfolio to address climate change activities. In Dano, NAPA actions were taken over by the Program of Agricultural Development (Programme Dévelopment de l'Agriculture; PDA), which has operated since 2013 with region-specific agendas. In south-west Burkina Faso, PDA focused on soil conservation. However, its activities were restricted mainly to networking and capacity building (N. P., Officer PDA Ioba province, Diebougou 05.03.2015). In the case of Dassari, NAPA is operated by the local office of the Agricultural Regional Agricultural Centers for Rural Development (Centres Agricoles Régionaux pour le Développement Rural; CARDER), and its activities include technical advice to farmers, provision of inputs for cotton cultivators, networking with related institutions, capacity building and monitoring of demonstration fields with pilot coping measures (A. N., officer CARDER Materi, Materi 11 March 2015).

Nonetheless, it was often stated that although climate change is not directly addressed, the regular activities carried out by local institutions, i.e., promotion of good agricultural practices, contributed indirectly to the increase in farmers' capabilities to combat several types of hazards, including those provoked by climate change (e.g., I. A., head of MAEP Materi, Tanguieta, 15 April 2013; S. M., director MARH, Dano 22, April 2015; E. D., agent NGO VARENA, Dano, 4 March 2015; A. M., Director executive NGO JURA Afrique, Tanguieta, 11 March 2015).

\section{Conclusions}

In short, this study reveals that farmer responses regarding climate change perception and their adaptation measures are often conjectural, not supported by statistical tests and inconsistent among each other. However, the broadness and diversity of climate change impacts are acknowledged by farmers and also handled in the same multifaceted way, but still site specifically. Moreover, the implemented measures tend to diverge from what is stated and reported, even by the actors themselves. Most stakeholders (including scientists) fail to acknowledge this complexity and to react accordingly. This questions the accuracy of the reports based on farmer statements lone and argues for a 'reality check' to test them rigorously.

The analyses of farmer perceptions and responses show that climate change-specific impacts on farming go beyond the well-known decline in yields, increase in pests and irregular provision of water; harm to livestock is not often reported. A priori farmer estimations on the importance of distressful climate elements are not always supported by quantitative in-depth analyses of specific responses, e.g., rainfall (floods) in Dassari is not as relevant as first stated, and in contrast, elements originally not considered hazards become such, e.g., windstorms in both catchments. Furthermore, the connection between the occurrence of climate-related hazards and the harm to households by extreme events (shocks) tends to be overestimated at least in the frequency of their occurrence. Attributing climate changes to mystical and supernatural causes does not prevent farmers from identifying their anthropogenic origins and reacting to the on-the-ground impacts via pragmatic actions. Climate change effects are rather recognized within a broader framework of concurring changes that involve social, ecological and institutional aspects.

Regarding the implementation of adaptation measures, institutionally, there is a conflict between what is intended and what is carried out. Although NAPAs exist, government agencies and NGOs lack operational and logistical capabilities, which limit their activities regarding sensitization and networking. Field activities, if taking place at all, refer to conventional extension of the promotion of good agricultural practices. On the farmer side, although 'only' $80 \%$ of them acknowledged changes in climate elements, they all carry out activities to support their adaptation to climate change. The practices prioritize soil conservation and crop species selection and are influenced by the particular socio-ecological settings. Nonetheless, cross-checking farmers' responses reveals that the drivers of crop species' selection are customary and not climatic, which explains the high rates of monocropping. 
This supports the hypothesis that farmers' coping measures and adaptation strategies address not only climate change and variability, but also other wide-ranging demands, such as food security, inflow of cash and livestock capitalization, as well as invoke the scrutiny of generalized assertions, such as the climate-determined crop selection.

Within this framework, we found that the determinants for the selection of coping measures are: (i) The short-term economic return: Farmers prioritize options that show quick success and are as secure as possible in allowing them access to cash, as was demonstrated by the selection of crops. Good examples are government programs that sponsor the cultivation of commodity crops, such as cotton, by providing agrochemicals and technical advice and guaranteeing the sale of the harvests. (ii) Compatibility with local ecological, social and institutional settings: Despite the geographic similarities of the study sites, comparing the farmers' responses reveals how soil loss or livestock feed provision are addressed through diverging, locally-adapted means. This implies divergences not only in technological criteria, but also in the institutional enforcement and the communities' adoption. (iii) Suiting to the customary farming traditions: Coping measures have to be tested in real conditions, so their social-ecological appropriateness and viability are validated. Normally, this occurs based on their long-term existence as in the case of agroforestry parklands, which are highly multifunctional and widely adopted. (iv) The influence of the national agricultural extension services (NAES): The long-term and consistent local presence of NAES is evident through the existing practices on-the-ground and the farmers' justifications to implement them, independent of the appropriateness of the practices and the dissemination methods.

In the study region, measures that fulfill these criteria exist, yet there is a lack of evaluation and validation of their appropriateness to support climate change adaptation, as well as the means for their optimization. For example, in the aforementioned subsidies program of commodity crops, quantifying the residual effect and diversion in the use of fertilizers and exploring the side benefits of organizing farmers in cooperatives for selling is still missing. In the case of agroforestry parklands, estimating the rates of firewood consumption against biomass regeneration, identifying the drivers of firewood collection and evaluating the alternatives to increase energy efficiency are necessary. In practice, implementing climate-change coping measures is a multiparty task, and therefore, the engagement of on-the-ground institutions is fundamental. NAES, local NGOs and NAPA's operative resources could close the gap in the identification, evaluation and monitoring of climate-smart agriculture instruments, but need to be empowered and provided with the necessary means to do so.

Supplementary Materials: The following are available online at http://www.mdpi.com/2225-1154/6/2/44/s1.

Acknowledgments: This research was financially supported by the West African Science Service Centre on Climate Change and Adapted Land Use (WASCAL) funded by the German Ministry of Education and Research (Bundesministerium für Bildung und Forschung; BMBF). I thank my colleagues John Lamers, Irit Eguavoen and Guido Lüchters, from the Center for Development Research (ZEF), University of Bonn, for their insights and expertise given in different phases of the drafting and analysis of this work; as well as to Margaret Jend, Pascal Ripplinger, Christoph Brummel and Anna Spiller for their engaged assistance along the manuscript production.

Conflicts of Interest: The author declares that there was no conflict of interest in the conceptualization, execution, analysis or writing of this paper.

\section{References}

1. Intergovernmental Panel on Climate Change. Contribution of Working Groups I, II and III to the Fifth Assessment Report of the Intergovernmental Panel on Climate Change; Climate Change 2014: Synthesis Report; Pachauri, R.K., Meyer, L.A., Eds.; Intergovernmental Panel on Climate Change: Geneva, Switzerland, 2014; 151p.

2. Collins, J.M. Temperature variability over Africa. J. Clim. 2011, 24, 3649-3666. [CrossRef]

3. Hulme, M.; Doherty, R.; Ngara, T.; New, M.; Lister, D. African Climate Change: 1900-2100. Clim. Res. 2001, 17, 145-168. [CrossRef]

4. Nicholson, S.E. Climatic and Environmental Change in Africa during the Last Two Centuries. Clim. Res. 2001, 17, 123-144. [CrossRef]

5. Sanchez, P. Soil fertility and hunger in Africa. Science 2002, 295, 2019-2020. [CrossRef] [PubMed] 
6. Challinor, A.; Wheeler, T.; Garforth, C.; Craufurd, P.; Kassam, A. Assessing the vulnerability of food crop systems in Africa to climate change. Clim. Chang. 2007, 83, 381-399. [CrossRef]

7. Valbuena, D.; Erenstein, O.; Homann-KeeTui, S.; Abdoulaye, T.; Claessens, L.; Duncan, A.J.; Gérard, B.; Rufino, M.C.; Teufel, N.; van Rooyen, A.; et al. Conservation Agriculture in mixed crop-livestock systems: Scoping crop residue trade-offs in Sub-Saharan Africa and South Asia. Field Crop. Res. 2012, 132, 175-184. [CrossRef]

8. Callo-Concha, D.; Gaiser, T.; Webber, H.; Tischbein, B.; Müller, M.; Ewert, F. Farming in the West African Sudan Savanna: Insights in the Context of Climate Change. Afr. J. Agric. Res. 2013, 8, 4693-4705. [CrossRef]

9. Niang, I.; Ruppel, O.C.; Abdrabo, M.A.; Essel, A.; Lennard, C.; Padgham, J.; Urquhart, P. Africa. Part B: Regional Aspects. Contribution of Working Group II to the Fifth Assessment Report of the Intergovernmental Panel on Climate Change. In Climate Change 2014: Impacts, Adaptation, and Vulnerability; Barros, V.R., Field, C.B., Dokken, D.J., Mastrandrea, M.D., Mach, K.J., Bilir, T.E., Chatterjee, M., Ebi, K.L., Estrada, Y.O., Genova, R.C., et al., Eds.; Cambridge University Press: Cambridge, UK; New York, NY, USA, 2014; pp. 1199-1265, ISBN 9789291691418.

10. Climate and Development Knowledge Network (CDKN). Available online: http://cdkn.org/resource/ highlights-africa-ar5 (accessed on 14 April 2015).

11. Roncoli, C. Ethnographic and participatory approaches to research on farmers' responses to climate predictions. Clim. Res. 2006, 33, 81-99. [CrossRef]

12. Nakashima, D.; Galloway McLean, K.; Thulstrup, H.; Ramos-Castillo, A.; Rubis, J. Weathering Uncertainty: Traditional Knowledge for Climate Change Assessment and Adaptation; UNESCO and United Nations University. Traditional Knowledge Initiative: Darwin, Australia, 2012; 120p, ISBN 9789230010683.

13. Adger, W.N.; Pulhin, J.M.; Barnett, J.; Dabelko, G.D.; Hovelsrud, G.K.; Levy, M.; Oswald, Ú; Vogel, C.H. Human security. Part A: Global and Sectoral Aspects. Contribution of Working Group II to the Fifth Assessment Report of the Intergovernmental Panel on Climate Change. In Climate Change 2014: Impacts, Adaptation, and Vulnerability; Field, C.B., Barros, V.R., Dokken, D.J., Mach, K.J., Mastrandrea, M.D., Bilir, T.E., Chatterjee, M., Ebi, K.L., Estrada, Y.O., Genova, R.C., et al., Eds.; Cambridge University Press: Cambridge, UK; New York, NY, USA, 2014; pp. 755-791, ISBN 9781107641655.

14. Kettle, N.P.; Dow, K.; Tuler, S.; Webler, T.; Whitehead, J.; Miller, K.M. Integrating scientific and local knowledge to inform risk-based management approaches for climate adaptation. Clim. Risk Manag. 2014, 4-5, 17-31. [CrossRef]

15. Ford, J.D.; Cameron, L.; Rubis, J.; Maillet, M.; Nakashima, D.; Willox, A.C.; Pearce, T. Including indigenous knowledge and experience in IPCC assessment reports. Nat. Clim. Chang. 2016, 6, 349-353. [CrossRef]

16. Cannon, T.D.; Müller-Mahn, D. Vulnerability, resilience and development discourses in context of climate change. Nat. Hazards 2010, 55, 621-635. [CrossRef]

17. Mertz, O.; Mbow, C.; Nielsen, J.Ø.; Maiga, A.; Diallo, D.; Reenberg, A.; Diouf, A.; Barbier, B.; Bouzou Moussa, I.; Zorom, M.; et al. Climate factors play a limited role for past adaptation strategies in West Africa. Ecol. Soc. 2010, 15, 25. [CrossRef]

18. Eguavoen, I.; zur Heide, F. Klimawandel und Anpassungsforschung in Äthiopien. Zeitschrift für Ethnologie 2012, 137, 97-118.

19. Saidou, A.; Kuyper, T.W.; Kossou, D.K.; Tossou, R.; Richards, R. Sustainable Soil Fertility Management in Benin: Learning from Farmers. NJAS-Wagening. J. Life Sci. 2004, 52, 349-369. [CrossRef]

20. Bryan, E.; Deressa, T.T.; Gbetibouo, G.A.; Ringler, C. Adaptation to climate change in Ethiopia and South Africa: Options and constraints. Environ. Sci. Policy 2009, 12, 413-426. [CrossRef]

21. Cuni Sanchez, A.; Fandohan, B.; Assogbadjo, A.E.; Sinsin, B. A countrywide multi-ethnic assessment of local communities' perception of climate change in Benin (West Africa). Clim. Dev. 2012, 4, 114-128. [CrossRef]

22. Yaro, J.A. The perception of and adaptation to climate variability/change in Ghana by small-scale and commercial farmers. Reg. Environ. Chang. 2013, 13, 1259-1272. [CrossRef]

23. Hillel, D.; Rosenzweig, C. Climate Change and Agroecosystems: Main Findings and Future Research Directions. In Handbook of Climate Change and Agroecosystems: Impacts, Adaptation and Mitigation; Hillel, D., Rosenzweig, C., Eds.; Imperial College Press: London, UK, 2011; pp. 429-435, ISBN 978-1-84816-655-4.

24. Bationo, A.; Vlek, P. The role of nitrogen fertilizers applied to food crops in the Sudano Sahelian zone of West Africa. In Soil Fertility Management in West African Land Use Systems; Renard, G., Neef, A., Becker, K., Oppen, M., Eds.; Margaf Verlag: Weikersheim, Germany, 1998; pp. 41-51. 
25. Schlesinger, W.H. Carbon sequestration in soils. Science 1999, 284, 2095. [CrossRef]

26. Food and Agriculture Organization of the United Nations (FAO). Investing in Sustainable Agricultural Intensification. The Role of Conservation Agriculture-A Framework for Action; Food and Agriculture Organization of the United Nations: Rome, Italy, 2008; 24p.

27. Naab, J.; Bationo, A.; Wafula, B.M.; Traore, P.S.; Zougmore, R.; Ouattara, M.; Tabo, R.; Vlek, P.L.G. African Perspectives on Climate Change and Agriculture: Impacts, Adaptation, and Mitigation Potential. In Handbook of Climate Change and Agroecosystems Global and Regional Aspects and Implications; ICP Series on Climate Change Impacts, Adaptation, and Mitigation; Hillel, D., Rosenzweig, C., Eds.; Imperial College Press: London, UK, 2012; Volume 2, pp. 85-106. ISBN 978-1-84816-983-8.

28. Steenhuis, T.S.; Masiyandima, M.C.; van de Giesen, N.; Diatta, S.; Windmeijer, P.N. The hydrology of inland valleys in the sub-humid zone of West Africa: Rainfall-runoff processes in the M'bé experimental watershed. Hydrol. Process. 2003, 17, 1213-1225. [CrossRef]

29. Sandwidi, J.P. Groundwater Potential to Supply Population Demand within the Kompienga Dam Basin in Burkina Faso. Ph.D. Thesis, Center for Development Research, University of Bonn, Bonn, Germany, 2007.

30. Mdemu, M.; Laube, W.; Barry, B. Temporal water productivity of tomato irrigated from a small reservoir and hand-dug wells in dry season cropping in the Upper East Region, Ghana. J. Appl. Irrig. Sci. 2010, 45, 75-93.

31. Crane, T.A.; Roncoli, C.; Hoogenboom, G. Adaptation to Climate Change and Climate Variability: The Importance of Understanding Agriculture as Performance. NJAS-Wagening. J. Life Sci. 2011, 57, 179-185. [CrossRef]

32. Maddison, D. The Perception of and Adaptation to Climate Change in Africa. Available online: http:/ / elibrary.worldbank.org/doi/pdf/10.1596/1813-9450-4308 (accessed on 3 June 2016).

33. Deressa, T.T.; Hassan, R.M.; Ringler, C.; Alemu, T. Yesuf, M. Determinants of farmers' choice of adaptation methods to climate change in the Nile Basin of Ethiopia. Glob. Environ. Chang. 2009, 19, 248-255. [CrossRef]

34. Ringler, C. Climate Change and Hunger: Africa's Smallholder Farmers Struggle to Adapt. EuroChoices 2010, 9, 16-21. [CrossRef]

35. Fosu-Mensah, B.Y.; Vlek, P.L.G.; MacCarthy, D.S. Farmers' perception and adaptation to climate change: A case study of Sekyedumase district in Ghana. Environ. Dev. Sustain. 2012, 14, 495-505. [CrossRef]

36. Nhemachena, C.; Hassan, R. Micro-Level Analysis of Farmers' Adaptation to Climate Change in Southern Africa; IFPRI Discussion Paper 00714; International Food Policy Research Institute: Washington, DC, USA, 2007.

37. Mertz, O.; Mbow, C.; Reenberg, A.; Diouf, A. Farmers' Perceptions of Climate Change and Agricultural Adaptation Strategies in Rural Sahel. Environ. Manag. 2009, 43, 804-816. [CrossRef] [PubMed]

38. Stoorvogel, J.; Smaling, E.M.A. Assessment of Soil Nutrient Depletion in Sub-Sahara 1983-2000; Winand Staring Centre: Wageningen, The Netherlands, 1990; 47p.

39. Giller, K.E.; Witter, E.; Corbeels, M.; Tittonell, P. Conservation agriculture and smallholder farming in Africa: The heretics' view. Field Crop. Res. 2009, 114, 23-34. [CrossRef]

40. Rusinamhodzi, L.; Corbeels, M.; van Wijk, M.T.; Rufino, M.; Nyamangara, J.; Giller, K.E. A meta-analysis of long-term effects of conservation agriculture on maize grain yield under rain-fed conditions. Agron. Sustain. Dev. 2011, 31, 657-673. [CrossRef]

41. Leakey, R. Living with the Trees of Life: Towards the Transformation of Tropical Agriculture; CABI: Wallingford, UK, 2012; 224p, ISBN 978-1780640983.

42. Ifejika, S.C. Resilient Adaptation to Climate Change in African Agriculture; Deutsches Institut für Entwicklungspolitik: Bonn, Germany, 2010; ISBN 978-3-88985-489-6.

43. Callo-Concha, D.; Ewert, F. Using the Concepts of Resilience, Vulnerability and Adaptability for the Assessment and Analysis of Agricultural Systems. Chang. Adapt. Soc.-Ecol. Syst. 2014, 1. [CrossRef]

44. Pretty, J.; Toulmin, C.; Williams, S. Sustainable intensification in African agriculture. Int. J. Agric. Sustain. 2011, 9, 5-24. [CrossRef]

45. Wheeler, T.; von Braun, J. Climate Change Impacts on Global Food Security. Science 2013, 341, 508-513. [CrossRef] [PubMed]

46. Paavola, J. Livelihoods, vulnerability and adaptation to climate change in Morogoro, Tanzania. Environ. Sci. Policy 2008, 11, 642-654. [CrossRef]

47. Barbier, B.; Yacouba, H.; Karambiri, H.; Zoromé, M.; Somé, B. Human Vulnerability to Climate Variability in the Sahel: Farmers' Adaptation Strategies in Northern Burkina Faso. Environ. Manag. 2009, 43, 790-803. [CrossRef] [PubMed] 
48. Diallo, I.; Sylla, M.B.; Giorgi, F.; Gaye, A.T.; Camara, M. Multimodel GCM-RCM Ensemble-Based Projections of Temperature and Precipitation over West Africa for the Early 21st Century. Int. J. Geophys. 2012, 972896. [CrossRef]

49. Ouédraogo, E. Soil Quality Improvement for Crop Production in Semi-Arid West Africa. Ph.D. Thesis, Wageningen University, Wageningen, The Netherlands, 2004.

50. Laube, W. Changing Natural Resource Regimes in Northern Ghana. Actors, Structure and Institutions; ZEF Development Studies; Lit Verlag Dr. W. Hopf. Münster: Münster, Germany, 2007; 392p, ISBN 978-3-8258-0641-5.

51. Windmeijer, P.; Andriesse, W. Inland Valleys in West Africa: An Agro-Ecological Characterization of Rice Growing Environments; International Institute for Land Reclamation and Improvement: Wageningen, The Netherlands, 1993; 160p, ISBN 9070754320.

52. Barbier, E.B. The economic linkages between rural poverty and land degradation: Some evidence from Africa. Agric. Ecosyst. Environ. 2000, 82, 355-370. [CrossRef]

53. Igue, A.M.; Floquet, A.; Stahr, K. Land use and farming systems in Benin. In Adapted Farming in West Africa: Issues, Potentials and Perspectives; Graef, F., Lawrence, P., von Oppen, M., Eds.; Verlag Ulrich E. Grauer: Stuttgart, Germany, 2000; pp. 227-238, ISBN 3-86186-315-4.

54. Institute National de la Statistique et de l'Analyse Economique (INSAE). Population Beninoise en Age de Voter en 2006. Available online: http:/ / web.stanford.edu/group/solarbenin/data/BeninDemographics/ Census\%20population\%20summary.pdf (accessed on 1 June 2017).

55. Stechert, C. Einsatz von Insektiziden im Baumwollanbau in Benin und deren Auswirkung auf Nicht-Zielorganismen. Ph.D. Thesis, Braunschweig University, Braunschweig, Germany, 2011.

56. World Bank. Climate Change Knowledge Portal. Available online: http://sdwebx.worldbank.org/ climateportal/ (accessed on 8 June 2016).

57. Republique du Benin, Departement de 1'Atacora. Plan de Development Economique et Social de Matéri. Available online: http:/ / www.ancb-benin.org/pdc-sdaconographies / PDC/Atacora / PDC \%20Mat $\%$ C $3 \%$ A9ri.pdf (accessed on 8 June 2006).

58. Institute National de la Statistique et Démographie. Resultats Preliminaires du Recensement General de la Population et de l'habitation de 2006. p. 49. Available online: http:/ / www.insd.bf/documents/publications / insd/publications/resultats_enquetes/autres\%20enq/Rapport_preliminaire_RGPH06.pdf (accessed on 1 June 2017).

59. Gleisberg-Gerber, K. Livelihoods and Land Management in the Ioba Province in South Western Burkina Faso; ZEF Working Paper 91; Center for Development Research: Bonn, Germany, 2012.

60. Schmengler, A.C. Modeling Soil Erosion and Reservoir Sedimentation at Hillslope and Catchment Scale in Semi-Arid Burkina Faso; Center for Development Research, Ecology and Development Series No. 80; Center for Development Research: Bonn, Germany, 2011; 236p, ISBN 9783940124319.

61. Climatic Research Unit of University of East Anglia. Available online: https://crudata.uea.ac.uk/cru/data/ temperature/ (accessed on 1 June 2017).

62. Eguavoen, I.; Wahren, J. Climate Change Adaptation in Burkina Faso: Aid Dependency and Obstacles to Political Participation; ZEF Working Paper 140; Center for Development Research: Bonn, Germany, 2015.

63. Eguavoen, I.; Schulz, K.; De Wit, S.; Weisser, F.; Müller-Mahn, D. Political dimensions of climate change adaptation. Conceptual reflections and African examples. In Handbook of Climate Change Adaptation, 2, Policy and Climate Change; Leal Filho, W., Ed.; Springer: Berlin/Heidelberg, Germany, 2013; pp. 1183-1199.

64. Zougmoré, R. Integrated Water and Nutrient Management for Sorghum Production in Semi-Arid Burkina Faso. Ph.D. Thesis, Wageningen University, Wageningen, The Netherlands, 2003.

65. Paeth, H.; Capo-Chichi, A.; Endlicher, W. Climate Change and Food Security in Tropical West Africa-A Dynamic-Statisitcal modelling Approach. Erdkunde 2008, 62, 101-115. [CrossRef]

66. Gijsbers, H.J.M.; Knevel, M.K. Dynamics and natural regeneration of woody species in farmed parklands in the Sahel region (Province of Passore, Burkina Faso). For. Ecol. Manag. 2004, 64, 1-12. [CrossRef]

67. Boffa, J.M. West African agroforestry parklands: Keys to conservation and sustainable management. Unasylva 2000, 51, 11-17.

68. Ministère de l'Environnement et de la Protection de la Nature (MEPN). Programme D'action National D'adaptation aux Changements Climatiques du Benin (PANA-Benin), Benin. 2008. Available online: http:/ /bj.chm-cbd.net/convention/conv-autres/convention-changements-climatiques/programmedaction-national-dadaptation-aux/PANA_BENIN.pdf-1 (accessed on 1 June 2017). 
69. Masih, I.; Maskey, S.; Mussá, F.E.F.; Trambauer, P. A review of droughts on the African continent: A geospatial and long-term perspective. Hydrol. Earth Syst. Sci. 2014, 18, 3635-3649. [CrossRef]

70. Anonymous; Climate Station Dano, Dano, Burkina Faso. Personal communication, 2013.

71. Anonymous; Climate Station Porga, Dassari, Benin. Personal communication, 2013.

72. National Oceanic and Atmospheric Administration (NOAA). Earth System Research Laboratory, University of Delaware. Available online: http://www.esrl.noaa.gov/psd/data/gridded/data.UDel_AirT_Precip.html (accessed on 8 June 2016).

73. Armitage, P.; Colton, T. Encyclopedia of Biostatistics; Wiley: New York, NY, USA, 2005; ISBN 978-0-470-84907-1.

(C) 2018 by the author. Licensee MDPI, Basel, Switzerland. This article is an open access article distributed under the terms and conditions of the Creative Commons Attribution (CC BY) license (http://creativecommons.org/licenses/by/4.0/). 